Studi Komparatif tentang Azas Legalitas

\title{
STUDI KOMPARATIF TENTANG ASAS LEGALITAS BERDASARKAN HUKUM PIDANA POSITIF INDONESIA DAN HUKUM PIDANA ISLAM
}

\author{
Leni Dwi Nurmala
}

\author{
Fakultas Hukum Universitas Gorontalo \\ lenitsaina@gmail.com
}

\begin{abstract}
The purpose of this study is to determine the legality principle according to positive criminal law in Indonesia and Islamic criminal law and to find out the comparison between the legality principle according to positive criminal law and Islamic criminal law. This type of research used in this research is using library research or known as literature research. The principle of legality in Indonesia's positive criminal law is a very fundamental principle. Because the principle of legality in criminal law is important to determine whether a criminal law regulation can be treated against a criminal act that occurs. In Islamic criminal law, the legality principle has a great influence on the judge's power, because the judge's power is very broad compared to the judge in positive law where the judge does not have sufficient power to act against the crime maker in accordance with the public interest. Comparison of the principle of legality between Islamic law and positive law. Whereas the application of the legality principle to positive criminal law and Islamic criminal law has similarities and differences. The similarity is that both apply the principle of legality in the legal process while the difference is that positive criminal law is the same in its application to offenses, whereas in Islamic criminal law there is a distinction between Jarimah qishas diyat, hudud, which is applied strongly, while in Jarimah ta'zir it is relaxed so that the benefit of society is fulfilled. In addition to having the similarities and differences above, the legality principle also has advantages and disadvantages, among others, in Islamic law the criminal provisions cannot be changed (added / reduced) because it is a provision from Allah which is standard, while in positive law the criminal provisions may change at any time. according to the times.
\end{abstract}

Keywords: legality principle, criminal law

\section{Intisari}

Tujuan penelitian ini Untuk mengetahui asas legalitas menurut hukum pidana positif Indonesia dan hukum pidana Islam dan Untuk mengetahui perbandingan antara asas 
legalitas menurut hukum pidana positif dengan hukum pidana Islam. Jenis penelitian yang digunakan dalam penelitian ini yakni menggunakan studi kepustakaan (library research) atau dikenal dengan penelitian literature. Asas legalitas dalam hukum pidana postif Indonesia merupakan asas yang sangat fundamental. Karena asas legalitas dalam hukum pidana penting untuk menentukan apakah suatu peraturan hukum pidana dapat diperlakukan terhadap tindak pidana yang terjadi. Dalam Hukum pidana Islam asas legalitas mempunyai pengaruh yang besar terhadap kekuasaan hakim, karena kekuasaan hakim sangat luas dibanding dengan hakim pada hukum positif dimana hakim tidak mempunyai kekuasaan yang cukup untuk bertindak terhadap pembuat kejahatan sesuai dengan kepentingan umum. Perbandingan mengenai asas legalitas antara hukum Islam dengan hukum hukum positif. Bahwa penerapan asas legalitas pada hukum pidana positif dan hukum pidana Islam mempunyai persamaan dan perbedaan. Persamaannya adalah sama-sama memberlakukan asas legalitas dalam proses hukum sedangkan dalam perbedaannya adalah bahwa hukum pidana positif dalam penerapannya sama terhadap delik, sedangkan pada hukum pidana Islam dibedakan antara jarimah qishas diyat, hudud, diterapkan secara kuat, sedangkan pada jarimah ta'zir diperlonggar sehingga kemaslahatan masyarakat terpenuhi. Selain mempunyai persamaan dan perbedaan tersebut diatas asas legalitas juga mempunyai kelebihan dan kelemahan antara lain dalam hukum Islam ketentuan pidananya tidak dapat dirubah-rubah (ditambah/dikurangi) karena sudah ketentuan dari Allah yang bersifat baku, sedangkan dalam hukum positif ketentuan pidananya suatu saat dapat berubah sesuai dengan perkembangan zaman.

Kata kunci: asas legalitas, hukum pidana

\section{Pendahuluan}

\subsection{Latar Belakang}

Asas legalitas dalam hukum merupakan asas yang sangat fundamental. Asas legalitas dalam hukum pidana sangat penting untuk menentukan apakah suatu peraturan hukum pidana dapat diberlakukan terhadap tindak pidana yang terjadi. Jadi apabila terjadi suatu tindak pidana, maka akan dilihat apakah terhadap ketentuan yang mengaturnya dan apakah aturan yang telah ada tersebut dapat diberlakukan terhadap tindak pidana yang terjadi.

Pada dasarnya asas legalitas lazim disebut juga dengan terminologi 'principle of legality', 'legaliteitbeginsel', 'non-retroaktif', 'de la legalite' atau 'ex post facto laws'. Ketentuan asas legalitas diatur dalam Pasal 1 ayat (1) Kitab

Undang-Undang Hukum Pidana (KUHP) Indonesia yang berbunyi: 'Tiada suatu 
peristiwa dapat dipidana selain dari kekuatan ketentuan undang-undang pidana yang mendahuluinya.

Untuk dapat menerapkan asas legalitas dalam hukum pidana, maka syarat pertama untuk dapat melakukan tindakan terhadap suatu perbuatan adalah adanya ketentuan dalam Undang-undang (pidana) yang merumuskan perbuatan pidana/tindak pidana itu dan memberikan sanksi terhadapnya. Hal ini disebabkan, pada hakekatnya suatu peraturan Undang-undang lebih-lebih peraturan hukum pidana hanya berlaku untuk masa yang akan datang. Artinya, untuk hal-hal yang terjadi sesudah peraturan itu diterapkan. Ketentuan seperti ini dalam hukum pidana dirumuskan dalam bahasa latin "Nullum Delictum Nolla poena, Sine Praevia Legi Poenali”.

Asas diatas sering juga dipakai istilah latin yaitu: "Nullum sine legi stricta" yang artinya bahwa : "tidak ada delik tanpa ketentuan yang tegas". Dalam bahasa yang lebih populer asas ini disebut asas legalitas. Dalam KUHP yang sekarang berlaku asas ini yang terdapat dalam Pasal 1 ayat (1) yang menyatakan : "Tiada suatu perbuatan dapat dipidana kecuali atas kekuatan aturan pidana dalam perundang-undangan yang telah ada, sebelum perbuatan dilakukan”. ${ }^{1}$

Berlakunya asas legalitas sebagaimana terurai diatas memberikan sifat "perlindungan terhadap undang-undang". Undang-undang pidana melindungi rakyat terhadap pelaksanaan kekuasaan yang tanpa batas dari pemerintah/penguasa, dengan kata lain, menjamin kebebasan individu terhadap kesewenang-wenangan pemerintah/penguasa. Disamping fungsinya melindungi, Undang-Undang pidana juga mempunyai fungsi instrumental, yaitu di dalam batas-batas yang ditentukan Undang-undang, pelaksanaan kekuasaan pemerintah tegas-tegas diperbolehkan.

Berlakunya asas legalitas yang sangat kaku/formal dalam sistem hukum pidana Indonesia telah menjadi "ganjalan” dalam upaya menciptakan keadilan. Hal ini disebabkan dalam pandangan masyarakat Indonesia berlakunya asas legalitas

\footnotetext{
${ }^{1}$ Soesilo, KUHP beserta penjelasannya, Bogor: Politeia,1996), pasal 1 (1)
} 
yang sangat formal bertentangan dengan nilai-nilai yang hidup dalam masyarakat Indonesia. Latar belakang pemikiran masyarakat Indonesia yang tidak bersifat formalitas dan terpecah-pecah kurang sesuai dengan konsep asas legalitas yang sangat kaku.

Berbanding dengan kehidupan masyarakat Indonesia yang mayoritas menganut agama Islam, maka apa yang terkandung dalam Al-Quran yang merupakan sumber hukum utama bagi mereka yang meyakininya sebagai syariat Islam. Dimana salah satu aturan pokok yang sangat penting dalam syariat Islam adalah aturan yang berbunyi : "sebelum ada nash (ketentuan), tidak ada hukum bagi perbuatan orang-orang yang berakal sehat". Dengan perkataan lain perbuatan seseorang yang cakap tidak mungkin dikatakan dilarang, selama belum ada nas (ketentuan) yang melarangnya, dan ia mempunyai kebebasan untuk melakukan perbuatan itu/meninggalkannya, sehingga ada nas yang melarangnya.

\subsection{Rumusan Masalah}

Berdasarkan latar belakang masalah diatas maka dengan penulis akan membatasi kajian yang akan dibahas, dengan rumusan masalah sebagai berikut :

1. Bagaimana asas legalitas pada hukum pidana positif Indonesia dan hukum pidana Islam?

2. Bagaimana perbandingan mengenai asas legalitas menurut hukum pidana positif dengan hukum pidana Islam?

\section{Metode Penelitian}

Jenis penelitian yang peneliti gunakan dalam menyusun penlitian ini adalah studi kepustakaan (library reseach) atau dikenal dengan penelitian literature. Menurut Dina Sujana, metode penelitian literature adalah metode yang berusaha menemukan, 
mengembangkan, mengkaji, menguji kebenaran suatu pengetahuan yang dilakukan dengan metode ilmiah. ${ }^{2}$

\section{Hasil dan Pembahasan}

\section{a. Asas Legalitas dalam Hukum Pidana Positif Indonesia}

Asas legalitas dalam hukum pidana merupakan asas yang sangat fundamental. Asas legalitas dalam hukum pidana penting untuk menentukan apakah suatu peraturan hukum pidana dapat diberlakukan terhadap tindak pidana yang terjadi. Jadi, apabila terjadi suatu tindak pidana, maka akan dilihat apakah telah ada ketentuan hukum yang mengaturnya dan apakah aturan yang telah ada tersebut dapat diberlakukan terhadap tindak pidana yang terjadi.

Dengan demikian, mengikuti asas legalitas dalam hukum pidana, maka syarat pertama untuk menindak terhadap suatu tindak pidana adalah adanya ketentuan dalam Undang-undang (pidana) yang merumuskan tindak pidana itu dan memberi sanksi terhadapnya. Hal ini disebabkan, pada hakikatnya suatu peraturan Undang-undang lebih-lebih peraturan hukum pidana hanya berlaku untuk masa yang akan datang. Artinya untuk hal-hal yang terjadi sesudah peraturan itu ditetapkan.

Dalam KUHP yang sekarang berlaku asas ini terdapat dalam Pasal 1 ayat (1) yang menyatakan : "tiada suatu perbuatan pidana dapat dipidana kecuali atas kekuatan aturan pidana dalam peraturan perundang-undangan yang telah ada, sebelum perbuatan dilakukan." 3

Mengingat asas legalitas merupakan asas yang sangat fundamental dalam hukum pidana, maka pemahaman terhadap berbagai aspek asas legalitas merupakan keharusan. Apabila dilihat dari isi kandungan, asas legalitas dalam hukum pidana memuat berbagai aspek yang berbeda: ${ }^{4}$

\footnotetext{
${ }^{2}$ Dina Sujana, Tuntunan Penyusunan Karya Ilmiah, (Bandung, Sinar Baru, 1989), hal.4.

${ }^{3}$ Lihat Pasal 1 ayat (1) Kitab Undang-undang Hukum Pidana.

${ }^{4}$ JE. Sahetapy, 1995 :6
} 
1. Tidak dapat dipidana Kecuali Berdasarkan Ketentuan Pidana Menurut Undangundang. Pasal 1 ayat (1) KUHP menetapkan bahwa tidak ada perbuatan yang dapat dipidana kecuali atas kekuatan aturan pidana menurut undang-undang yang telah ada sebelumnya. Penentuan dapat dipidananya suatu perbuatan harus terjadi melalui Undang-undang dalam arti formal atau berdasarkan kekuatan undang-undang dalam arti materiil yang dibuat oleh pembentuk undang-undang dalam arti formal untuk berbuat demikian.

2. Tidak ada Penerapan Undang-undang Pidana berdasarkan Analogi. Penerapan undang-undang berdasarkan analogi menerapkan suatu ketentuan atas suatu kasus yang tidak termasuk didalamnya. Karena analogi menerapkan suatu peraturan pada suatu perbuatan yang sebenarnya tidak diatur, maka analogi berarti memperluas berlakunya suatu peraturan perundang-undangan dengan mengabstrasikannya menjadi aturan hukum yang menjadi dasar menerapkan aturan yang bersifat umum itu kepada perbuatan kongkrit yang tidak diatur oleh Undang-Undang. Larangan penggunaan Analogi ini juga berkaitan dengan fungsi hukum pidana, yaitu fungsi melindungi dari undang-undang pidana dan penerapan aturan pidana berdasarkan analogi tidak mungkin digabungkan.

3. Tidak Boleh Ada Delik Yang Kurang Jelas. Syarat Lex Certa berarti Undangundang harus cukup jelas. Keharusan suatu tindak pidana secara jelas dimaksudkan agar: a) aturan tersebut dapat menjadi pegangan bagi warga masyarakat dalam memilih tingkah lakunya, dan b) untuk memberikan kepastian kepada penguasa mengenai batas-batas kewenangannya.

4. Ketentuan Pidana Tidak Berlaku Surut. Berdasarkan ketentuan Pasal 1 ayat (1) KUHP ditegaskan, bahwa tidak ada suatu perbuatan yang dapat dipidana kecuali atas kekuatan pidana menurut Undang-undang "yang telah ada sebelumnya". Dengan demikian, berdasarkan ketentuan tersebut dapat disimpulkan, bahwa aturan pidana pada hakikatnya berlaku untuk masa yang akan datang (kecuali ditentukan oleh undang-undang), tidak berlaku surut. Pengecualian atas larangan berlaku surutnya aturan pidana tersebut dimungkinkan, apabila berlaku surutnya aturan 
pidana tersebut untuk kepentingan (meringankan) terdakwa sebagaimana ditentukan dalam Pasal 1 ayat (2) KUHP, jika sesudah perbuatan dilakukan ada perubahan dalam perundang-undangan, dipakai aturaran yang paling meringankan bagi terdakwa. ${ }^{5}$ Berdasarkan ketentuan tersebut bahwa suatu aturan pidana dapat berlaku surut apabila ketentuan yang ada sesudah perbuatan yang dilakukan terdakwa tersebut lebih meringankan terdakwa. Contoh: Budi pada tanggal 5 januari 1985 ditangkap oleh polisi karena tertangkap basah sedang mengambil jam tangan milik temannya, Arjuna. Setelah selesai di proses penyidikan oleh polisi, perkaranya dilimpahkan ke kejaksaan/penuntut umum. Berdasarkan ketentuan yang berlaku saat itu, Budi didakwa melanggar Pasal 362 KUHP dengan ancaman pidana maksimum pidana penjara lima tahun. Perkara Budi diadili pada tanggal 5 Agustus 1985, sementara pada tanggal 5 maret 1985 terjadi perubahan terhadap ketentuan pasal 362 tidak lagi diancam dengan penjara 5 tahun, tetapi hanya pidana penjara satu tahun. Berdasarkan ketentuan Pasal 1 ayat (2) KUHP, ketentuan pidana yang ada sesudah perbuatan itu dilakukan Budi dapat diberlakukan surut terhadap dirinya, karena aturan yang baru tersebut lebih meringankan.

5. Tidak Ada Pidana Lain Kecuali yang ditentukan Undang-Undang. Didalam hukum pidana, berlaku aturan bahwa undang-undang menentukan pidana-pidana yang dijatuhkan. Dalam KUHP pidana yang dapat dijatuhkan adalah sebagaimana yang ditentukan dalam Pasal 10 KUHP. ${ }^{6}$ Ketentuan ini berlaku juga untuk UndangUndang diluar KUHP sepanjang tidak diatur lain dalam Undang-undang khusus. ${ }^{7}$

Sekalipun asas legalitas telah secara ketat memberikan rambu-rambu dalam penerapan suatu aturan pidana, namun sering sekali sangat sulit untuk mengetahui apakah suatu kasus tertentu termasuk atau tidak dalam ketentuan pidana. Dengan demikian hakim wajib menetapkan arti yang tepat dari ketentuan pidana tersebut, hakim harus menafsirkan ketentuan pidana tersebut.

\footnotetext{
${ }^{5}$ Lihat Pasal 1 ayat (2) KUHP.

${ }^{6}$ Lihat Pasal 10 KUHP.

${ }^{7}$ Lihat Pasal 103 KUHP.
}

Suloh: Jurnal Fakultas Hukum Universitas Malikussaleh, Vol. 9, No. 1, April 2021, pp. 56- 66 


\section{b. Asas Legalitas dalam Hukum Islam}

Istilah asas legalitas tidak ditemukan dalam hukum Islam, namun secara substansial hukum Islam menganut asas legalitas ini. Dalam hal pidana ini Islam mempunyai beberapa kaidah pokok yaitu kaidah yang menyatakan bahwa: tidaklah dapat dianggap sebagai suatu tindak pidana bagi orang yang melakukan perbuatan atau meninggalkan perbuatan selama tidak ada nas dengan jelas. Oleh sebab itu tidaklah dapat dipertanggungjawabkan orang yang melakukan perbuatan atau meninggalkan perbuatan tersebut". ${ }^{8}$ Hal ini dapat kita singkat dengan kaidah yang berbunyi; Artinya : "Tidak ada hukuman dan tidak ada tindak pidana (jarimah) kecuali dengan adanya nash”.

Dengan kata lain, perbuatan seseorang yang cakap (ahliyyah; mukalaf) tidak mungkin dinyatakan sebagai pelanggaran selama belum ada nas yang melarangnya, dan ia mempunyai kebebasan untuk melakukan perbuatan itu atau meninggalkannya sampai ada nas yang menentukan.

Kaidah pokok lain adalah: "Pada dasarnya semua perkara dan perbuatan dibolehkan". Dengan kata lain, semua perbuatan dan semua sikap tidak berbuat dibolehkan dengan kebolehan yang dinyatakan oleh syara'. Selama belum ada nas yang melarang, tidak ada tuntutan terhadap semua perbuatan dan sikap tidak berbuat.

Disamping kaidah diatas, masih ada kaidah pokok lain yang berhubungan dengan asas legalitas menurut syara', yaitu: "Hanya orang yang bisa diberi taklif (pembebanan) yang mempunyai kesanggupan untuk mengerjakan dan memahami dalil taklif." Dan juga menurut syara': "Hanya pekerjaan yang dibebankanlah yang mungkin dilakukan dan di sanggupi dan diketahui oleh orang mukalaf sedemikian rupa sehingga bisa mendorongnya untuk melakukan pekerjaan itu."9

Dalam Al-quran ada beberapa ayat yang berhubungan dengan asas legalitas. Allah SWT tidak menjatuhkan suatu siksa atas umat manusia kecuali sudah ada

\footnotetext{
8 Juhana, S. Praja, dan Ahmad Sihabudin, Delik Agama dalam Hukum Pidana di Indonesia, (Bandung: Angkasa, 1982)

${ }^{9}$ Hafizd Dasuki, Ensklopedi Hukum Islam, (Jakarta: Ichtiar Baru van Hoeve, 1997), hal. 129
}

Suloh: Jurnal Fakultas Hukum Universitas Malikussaleh, Vol. 9, No. 1, April 2021, pp. 57- 66 
penjelasan dan pemberitahuan melalui rasul- rasul-Nya, dan beban (kewajiban) yang diberikan kepada mereka, yakni perkara yang disanggupi, sebagaimana tampak dalam firman-Nya diantaranya yaitu:

(1) Surah Al-Isra' ayat 15 : Artinya: "Dan seseorang yang berdosa tidak dapat memikul dosa orang lain, dan Kami (Allah) tidak akan mengazab sebelum Kami mengutus seorang rasul." 10

(2) Surat Al- Qashash ayat 59 : Artinya: "Dan tidak pernah tuhanmu membinasakan kota-kota sebelum Dia mengutus seorang Rasul yang membacakan ayat-ayat Kami kepada mereka." 11

(3) Surat Al- An'am ayat 19 : Artinya: “ .... Supaya dengan dia Aku memberi peringatan kepadamu dan kepada orang-orang yang sampai Al-Qur'an (kepadanya) .... ${ }^{12}$

(4) Surat Al-Baqarah ayat 286 : Artinya: "Allah tidak membebankan seseorang kecuali sesuai dengan kemampuannya."13

Baik dalam syara' maupun hukum Eropa keduanya menggunakan asas legalitas, yaitu "tidak ada tindak pidana dan tidak ada hukuman selain atas aturan pidana dalam nash atau Undang-undang”. Tetapi dalam menerapkan prinsip tersebut terdapat beberapa perbedaan antara syara' dan hukum Eropa.

1. Masa Penerapan. Syari'at Islam telah menerapkan asas legalitas sejak wahyu diturunkan, khususnya pada periode Madinah, jauh sebelum dikenal dan diterapkan oleh hukm Eropa (abad ke-18)

2. Cara Penerapan. Dalam Syari'at Islam ada tiga cara penerapan asas legalitas, yaitu : Pertama, pada tindak pidana yang gawat dan sangat mempengaruhi keamanan dan ketentraman masyarakat, yaitu tindak pidana hudud (hukuman yang ditetapkan batasnya oleh nash) dan qisas (pembalasan setimpal), asas legalitas

\footnotetext{
${ }^{10} \mathrm{Al}-\mathrm{Qur}$ 'an (17):15

${ }^{11}$ Al-Qur'an (28):59

${ }^{12}$ Al-Qur'an (6): 19

${ }^{13} \mathrm{Al}$-Qur'an (2):286
}

Suloh: Jurnal Fakultas Hukum Universitas Malikussaleh, Vol. 9, No. 1, April 2021, pp. 58- 66 
dilaksanakan secara teliti dengan mencantumkan satu persatu hukuman bagi setiap tindak pidana.

Kedua, pada tindak pidana yang tidak begitu berbahaya, yaitu tindak pidana takzir pada umumnya, syara' memberikan kelonggaran dalam penerapan asas legalitas dari segi hukuman. Bagi tindak pidana tersebut syara' hanya menyediakan sejumlah hukuman untuk dipilih oleh hakim sesuai dengan peristiwa-peristiwa yang dihadapi.

Ketiga, pada tindak pidana takzir yang diancam hukuman demi kemaslahatan umum, syara' memberikan kelonggaran dalam penerapan asas legalitas dari segi penentuan macam tindak pidana, karena syari'at hanya mencakupkan dengan membuat suatu nash (ketentuan) umum yang bisa mencakup setiap perbuatan yang mengganggu kepentingan dan ketentraman masyarakat.

3. Ketentuan pidana. Dalam Syari'at Islam nas-nas yang menentukan macam tindak pidana bersifat umum dan elastis, sehingga bisa menampung semua peristiwa. Kemudian dalam tindak pidana hudud dan qisas keumuman agak dibatasi. Namun, untuk tindak pidana lainnya keumuman tersebut berlaku sepenuhnya seperti pada tindak pidana takzir biasa. Untuk tindak pidana takzir, karena untuk mewujudkan kemaslahatan umum, elastisitas nas-nas yang menentukan tindak pidana lebih kuat sehingga cukup dengan menyebutkan sifat-sifatnya. Oleh karena itu, suatu perbuatan tidak mungkin diketahui sebagai tindak pidana kecuali sesudah terjadi. Keumuman dan elastisitas nas mempunyai pengaruh terhadap kemampuan syari'at dalam menghadapi keadaan dan lingkungan.

4. Hukuman, pada dasarnya syari'at menentukan macam hukuman yang jelas sehingga tidak mungkin bagi hakim untuk menciptakan hukuman sendiri. Ketentuan hukum semacam itu berlaku pada tindak pidana hudud dan qishas, yaitu tindak pidana yang sangat mengganggu keamanan dan ketentraman masyarakat. Pada tindak pidana ta'zir, dengan segala macamnya, syara' hanya menentukan sejumlah hukuman yang sesuai atau menjatuhkan hukuman antara batas tertinggi dan terendah, menghentikan atau memerintahkan pelaksanaan hukuman dengan segera. 
b. Perbandingan Mengenai Asas Legalitas Menurut Hukum Pidana Positif Dengan Hukum Pidana Islam.

Untuk mengetahui perbedaan asas legalitas menurut Hukum Pidana Positif dan Hukum Pidana Islam dapat dilihat pada tabel dibawah ini:

\begin{tabular}{|c|c|}
\hline Pidana Positif & Hukum Pidana Islam \\
\hline $\begin{array}{l}\text { 1. masa penerapan dalam hukum positif } \\
\text { asas legalitas diterapkan pada abad ke- } \\
18 \text { masehi. }\end{array}$ & $\begin{array}{l}\text { 1. Masa Penerapan Dalam Hukum Pidana } \\
\text { Islam Asas Legalitas Diterapakan Sejak } \\
\text { Wahyu Diturunkan, Khususnya Pada } \\
\text { Periode Madinah }\end{array}$ \\
\hline $\begin{array}{l}\text { 2. cara penerapan asass legalitas dalam } \\
\text { hukum pidana positif untuk semua } \\
\text { tindak pidana sama saja, pada } \\
\text { mulanya hukum pidana positif } \\
\text { menggunakan cara pertama hukum } \\
\text { pidana Islam untuk semua tindak } \\
\text { pidana kemudian mengambil cara } \\
\text { kedua yaitu dengan mempersempit } \\
\text { kekuasaan hakim dalam memilih dan } \\
\text { menentukan besarnya, dan pada } \\
\text { akhirnya cara kedualah yang } \\
\text { diterapkan. }\end{array}$ & $\begin{array}{l}\text { 2. Cara penerapan dalam hukum pidana } \\
\text { Islam ada tiga cara penerapan yaitu: } \\
\text { a. Pada tindak pidana yang gawat dan } \\
\text { sangat mempengaruhi keamanan dan } \\
\text { ketentraman mayarakat. } \\
\text { b. Pada tindak pidana yang tidak begitu } \\
\text { berbahaya } \\
\text { c. Pada tindak pidana ta'zir yang } \\
\text { diancam hukuman demi kemaslahatan } \\
\text { umum }\end{array}$ \\
\hline $\begin{array}{l}\text { 3. Ketentuan pidana, dalam hukum } \\
\text { pidana positif setiap tindak pidana } \\
\text { bisa diidentifikasi seteliti mungkin } \\
\text { dengan menyebutkan unsure-unsur } \\
\text { materiilnya, oleh karena itu terbatas } \\
\text { sekali tindak pidana yang dimasukkan } \\
\text { dalam suatu aturan pidana. }\end{array}$ & $\begin{array}{l}\text { 3. Ketentuan hukuman, dalam hukum } \\
\text { pidana Islam nas-nas yang menentukan } \\
\text { macam tindak pidana bersifat umum dan } \\
\text { elastis sehingga bisa menampung semua } \\
\text { peristiwa. }\end{array}$ \\
\hline
\end{tabular}




\begin{tabular}{|c|c|}
\hline $\begin{array}{l}\text { 4. Hukuman, dalam hukum pidana } \\
\text { positif untuk setiap tindak pidana } \\
\text { disediakan satu atau dua macam } \\
\text { hukuman dengan batas tertinggi dan } \\
\text { terendah. }\end{array}$ & $\begin{array}{l}\text { 4. Hukuman, pada dasarnya hukum pidana } \\
\text { Islam menentukan macam hukuman yang } \\
\text { jelas sehingga tidak mungkin bagi hakim } \\
\text { untuk menciptakan hukuman sendiri. }\end{array}$ \\
\hline
\end{tabular}

Sedangkan persamaannya antara hukum pidana positif dan hukum pidana Islam adalah keduanya sama-sama memberlakukan asas legalitas dalam proses hukum.

Selain mengetahui perbedaannya dapat juga dilihat kelemahan dan kelebihannya yang dapat dilihat pada tabel dibawah ini:

\begin{tabular}{|c|c|c|}
\hline & Kelebihan & Kelemahan \\
\hline Hukum Pidana Islam & $\begin{array}{l}\text { 1. Dalam asas pidana } \\
\text { islam tidal mengenal } \\
\text { penghapusan tindak } \\
\text { pidana karena jabatan } \\
\text { sehingga tidak dapat } \\
\text { dipidana, karena pada } \\
\text { hakekatnya setiap } \\
\text { orang yang telah } \\
\text { mukallaf harus } \\
\text { bertanggungjawab } \\
\text { terhadap apa yang ia } \\
\text { lakukan, terlebih lagi } \\
\text { karena jabatan. }\end{array}$ & $\begin{array}{l}\text { 1. Hukum Islam tidak dikenal } \\
\text { didalam perundang-undangan } \\
\text { Indonesia sebagai system hukum } \\
\text { karena Indonesia menganut } \\
\text { system hukum Eropa kontinental } \\
\text { sehingga pelaku tidak hanya } \\
\text { dapat dipidana dengan merujuk } \\
\text { pada KUHP (hukum materiil) dan } \\
\text { KUHAP (hukum formil) saja } \\
\text { yang bersifat memaksa } \\
\text { (dwinginrecht) dan tidak boleh } \\
\text { dikenakan dengan hukum Islam. } \\
\text { 2. Dalam hukum pidana Islam } \\
\text { tidak ada lembaga yang bersifat } \\
\text { yuridis formil tertentu untuk } \\
\text { mengawal pelaksaannya di }\end{array}$ \\
\hline
\end{tabular}




\begin{tabular}{|c|c|c|}
\hline & 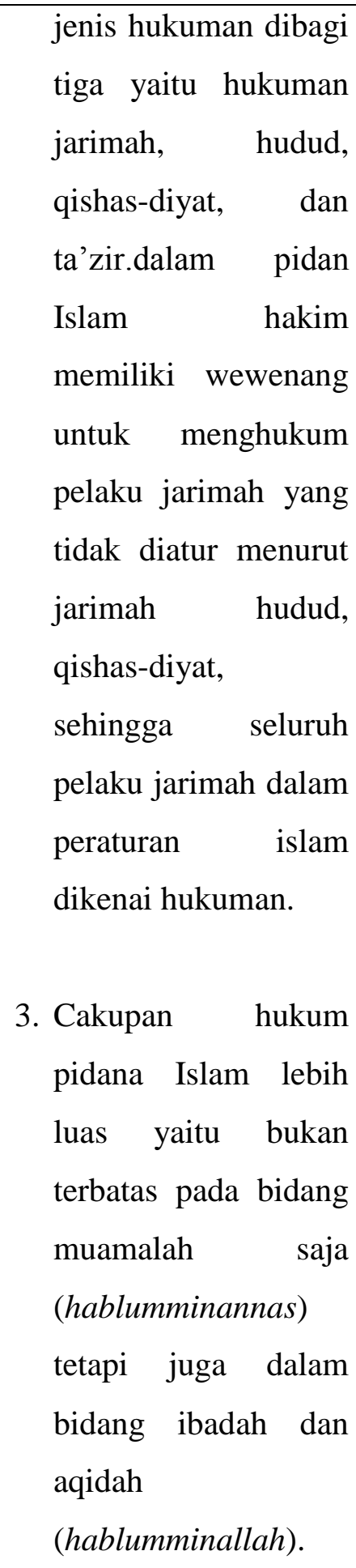 & $\begin{array}{l}\text { 3. Hukum pidana Islam yang } \\
\text { berkaitan dengan pidana jarimah } \\
\text { hudud tidak dapat dirubah-rubah } \\
\text { (ditambah/dikurangi) lagi baik } \\
\text { deraksi maupun ketentuan } \\
\text { pidananya karena sudah baku dari } \\
\text { Allah. }\end{array}$ \\
\hline Hukum Pidana Positif & 1. Hukum pidana positif & 1. Penghapusan tindak \\
\hline
\end{tabular}




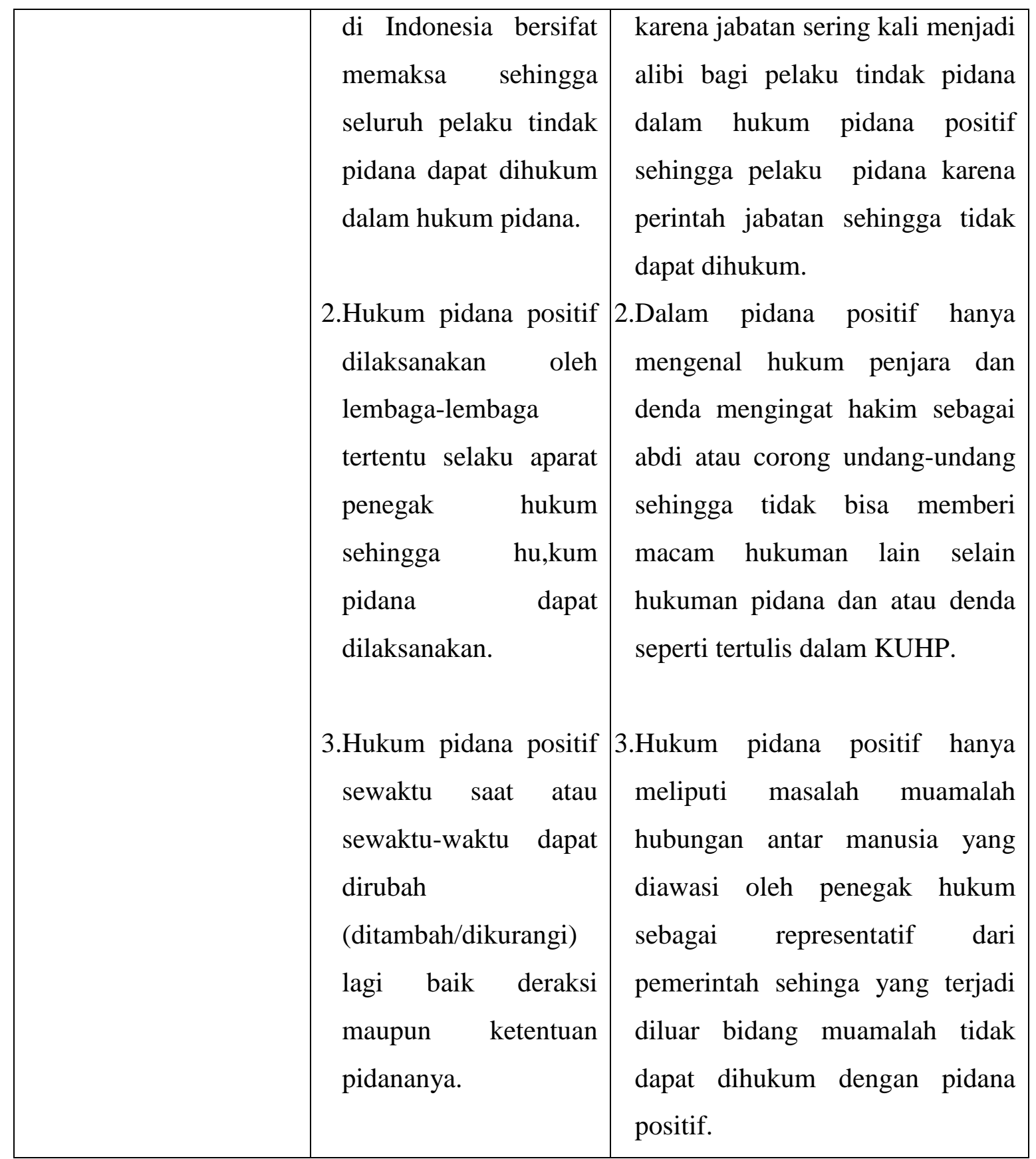




\section{Kesimpulan}

Berangkat dari uraian keseluruhan pembahasan diatas, penyusun dapat mengambil kesimpulan tentang asas legalitas yang terdapat pada perumusan masalah yaitu, sebagai berikut :

Asas legalitas dalam hukum pidana postif Indonesia merupakan asas yang sangat fundamental. Karena asas legalitas dalam hukum pidana penting untuk menentukan apakah suatu peraturan hukum pidana dapat diperlakukan terhadap tindak pidana yang terjadi. Jadi apabila terjadi suatu tindak pidana maka akan dilihat apakah terhadap ketentuan hukum yang mengaturnya dan apakah aturan yang telah ada tersebut dapat diberlakukan terhadap tindak pidana yang terjadi. Maka dengan dengan diterapkannya asas legalitas tersebut para hakim tidak bisa bertindak sekehendaknya atau semenamena.

Sedangkan dalam hukum pidana Islam asas legalitas mempunyai pengaruh yang besar terhadap kekuasaan hakim, karena kekuasaan hakim sangat luas dibanding dengan hakim pada hukum positif dimana hakim tidak mempunyai kekuasaan yang cukup untuk bertindak terhadap pembuat kejahatan sesuai dengan kepentingan umum. Asas legalitas dalam bahasa latinnya disebit dengan "Nullum Delictum Nolla Poena, Sine Praevia Legi Poenali" yang artinya tiada suatu perbuatan dapat dipidana kecuali atas kekuatan aturan pidana dalam perundang-undnagan yang telah ada, sebelum perbuatan dilakukan. Asas legalitas ini dirumuskan dalam pasal 1 ayat 1 KUHP. Pada prinsipnya hukum pidana positif dan hukum pidana Islam adalah sama tetapi dalam penerapannya yang berbeda.

Perbandingan mengenai asas legalitas antara hukum Islam dengan hukum hukum positif. Seperti yang telah dijelaskan didepan bahwa penerapan asas legalitas pada hukum pidana positif dan hukum pidana Islam mempunyai persamaan dan perbedaan. Persamaannya adalah sama-sama memberlakukan asas legalitas dalam proses hukum sedangkan dalam perbedaannya adalah bahwa hukum pidana positif dalam penerapannya sama terhadap delik, sedangkan pada hukum pidana Islam dibedakan antara jarimah qishas diyat, hudud, diterapkan secara kuat, sedangkan pada jarimah ta'zir diperlonggar sehingga kemaslahatan masyarakat terpenuhi. Selain mempunyai 
persamaan dan perbedaan tersebut diatas asas legalitas juga mempunyai kelebihan dan kelemahan antara lain dalam hukum Islam ketentuan pidananya tidak dapat dirubahrubah (ditambah/dikurangi) karena sudah ketentuan dari Allah yang bersifat baku, sedangkan dalam hukum positif ketentuan pidananya suatu saat dapat berubah sesuai dengan perkembangan zaman.

\section{Saran}

1. Diharapkan kepada seluruh aparat penegak hukum yang terkait untuk senantiasa dan memperkaya diri dengan berbagai disiplin ilmu terutama ilmu-ilmu hukum yang selalu berkembang sejalan dengan perkembangan manusia dan masyarakat Indonesia.

2. Diharapkan penegak hukum jangan hanya terpaku kepada perundang-undangan yang tertulis semata, namun pertimbangkanlah rasa keadilan. Kepentingan masyarakat serta kepentingan moral agar Negara dan bangsa Indonesia menjadi suatu dambaan bagi manusia Indonesia yang mendambakan keadilan dan kemakmuran.

\section{Daftar Pustaka}

Abdullah Mujiono, Dialektika Hukum Islam dan Perubahan Sosial, Solo, UMS Press, 2003.

Adami,Chazawi, Pelajaran Hukum Pidana, (stelsel pidana, tindak pidana, teori-teori pemidanaan dan batas berlakunya hukum pidana), Jakarta, Raja Grafindo Persada, 2002.

Bambang Waluyo, Penelitian Hukum Dalam Praktek, cet.ke-3, Jakarta, Sinar Grafika, 2002.

Erdiant Effendi, Hukum Pidana di Indonesia, Suatu Pengantar, Refika Aditama, Bandung, 2016.

Fuad Usfa, dkk, Pengantar Hukum Pidana, UMM, Pres, 2004. 
Jan Remelink, Hukum Pidana, Komentar Atas Pasal-Pasal Terpenting Dari Kitab UndangUndang Hukum Pidana Belanda Dan Padanannya Dalam Kitab Undang-Undang Hukum Pidana Indonesia, Gramedia Pustaka Utama, Jakarta, 2003.

Kadri Husin dan Budi Riski Husin, Sistem peradilan Pidana di Indonesia, Jakarta, Sinar Grafika, 2016.

Kitab Undang-Undang Hukum Pidana

Moeljatno, Asas-asas Hukum Pidana, Jakarta, Rineka Cipta, 1993.

Nanang Sambas, Perkembangan Hukum Pidana dan Asas-asas dalam RKUHP, Refika Aditama, Bandung, 2019. 